\title{
Tüketicilerin Yatak Seçim Davranışlarının İncelenmesi
}

\author{
Havva TOKGÖZ1 ${ }^{(\mathbb{D})}$, Sibel KAPLAN ${ }^{* 2}$ () \\ 1,2Süleyman Demirel Üniversitesi, Mühendislik Fakültesi, Tekstil Mühendisliği Bölümü, 32260, Isparta, Türkiye
}

(Alınış / Received: 18.01.2019, Kabul / Accepted: 11.07.2019, Online Yayınlanma / Published Online: 30.08.2019)

Anahtar Kelimeler

Yatak,

Konfor,

Tüketici tercihleri,

Anket
Özet: Günümüzde insanların hayat standartlarının artmasıyla, günümüzün üçte birini geçirdiğimiz uyku ortamını oluşturan tekstil ürünlerinden beklentileri de artmıştır. Konfor kavramı, giysiler için olduğu gibi yatak mikroklimasını oluşturan tekstil bileșenleri için de önemlidir. Bu çalışmada, bir grup tüketicinin yatak seçiminde önem verdiği parametreler, konforlu uyku için gerekli şartlar, reklamların satın alma davranışları üzerindeki etkileri, tercih edilen yatakların kullanım süreleri, uyku sırasında yaşanan fizyolojik problemler konularındaki görüşleri anket yöntemiyle alınmıştır. Literatürde genellikle belirlenen yatakların sertlik-yumuşaklık algısı, yarattığı sağlık problemleri ile ilgili anketler ve subjektif denemeler mevcuttur. 320 kişinin katıldığı ankette kaliteli uyku için önem verilen parametreler incelendiğinde, en önemli faktörün yatak konforu olduğu, hammadde ve bitim işlemleri ile sağlanan fonksiyonelliklerin de ön planda olduğu tespit edilmiştir. Termal konforun yanında, çoğunluğun hissettiği sırt/omurga ve bel ağrılarına yönelik mekanik desteklerin de yatak tasarımında önemli olduğu tespit edilmiștir. Tüketicilerin yatak tercihinde reklamlardan özellikle ortopedik özellikler, kullanım kolaylığı ve sağlıkla ilgili özellikler konusunda etkilendikleri tespit edilmiştir.

\section{Investigation of Consumers' Mattress Selection Behaviors}

\section{Keywords}

Mattress,

Comfort,

Consumer preferences, Survey

\begin{abstract}
Nowadays, with the increase of people's living standards, the expectations from textile products constituting sleeping environment in which we spend one third of a day have increased. The concept of comfort is also vital for the textile components that create the mattress microclimate as in clothes. In this study, the opinions of a group of consumers about the parameters that they consider in mattress selection, the conditions for a comfortable sleep, the effects of advertisements on the buying behaviors, the usage periods of the preferred mattresses and the physiological problems during sleep were taken by a survey. In the literature, studies generally cover hardness-softness perception of the mattresses, questionnaires and subjective trials related to health problems. According to the results of 320 respondent; comfort, material and functional finishing applications are the parameters important for a comfortable sleep. Besides thermal comfort, mechanical supports designed to prevent back/spine and waist area pains are important points for mattress design. Moreover, consumers were influenced by advertisements in mattress preference for orthopedic properties, functional properties related to easy care and health issues.
\end{abstract}

\section{Giriş}

Uyku, zihinsel ve fiziksel sağlı̆̆ımızı her gün yenilememiz için önemli bir fizyolojik bileşendir [1]. Uyku yetersizliği vücudu stres altına sokar ve gün boyunca adrenalin, kortizol ve diğer stres hormonlarının daha fazla salgılanmasına yol açar. Bu hormonlar kan basıncındaki dalgalanmaları engelleyerek kişiyi kalp damar hastalıklarına açık hale getirir [2]. Her yıl uyku bozuklukları ABD'li yetişkin popülasyonunun \%40'ını etkilemektedir [3]. İyi bir uyku normal günlük ritmi kolaylaştırır, yorgunluğu azaltır ve fiziksel yenilenmeyi sağlar. Uyku kalitesine etki eden çok sayıda çevresel, ruhsal ve fizyolojik neden bulunmaktadır. Bu etkenler; yaş, cinsiyet, rrk, fiziksel aktivite, medeni durum, yaşam dönemi (menopoz, gebelik vs.), gelir, yaşama biçimi, ilaç kullanımı, alkol ve madde kullanımı, çevre vb. 
olarak sıralanabilir. Genel olarak toplam uyku süresi yaşla azalmaktadır. Yaşlanmayla beraber yavaş dalga uykusu ve bütün olarak uyku etkinliği erkeklerde kadınlardan daha fazla azalmaktadır. Fiziksel aktivite bireyin yorulmasına neden olmakta ve daha kolay uykuya dalmasını sağlamaktadır. Çalışma düzeni vardiya şeklinde olan kişilerin değişen uyku saatlerine uyum sağlaması zor olmaktadır. Bazı yiyecek ve içecekler içerikleri ve tüketim miktarları nedeniyle uykuyu etkilemektedir. Protein içeren yiyecekler uykuya dalmayı kolaylaştırırken, karbonhidratlar da seratonin düzeyini etkileyerek rahatlık ve sakinlik hissi sağlamaktadır [4]. Tüm bu etkenlerin yanı sıra uyku kalitesi, çeşitli çevresel faktörler, sıcaklık, ışık, gürültü ve yatak kalitesi tarafından da etkilenmektedir. Yatak malzemesi de uyku kalitesi üzerinde etkilidir ve uyku sorunlarının \%7'si uyku sırasında omurgaya binen yükten ve rahatsız yataklardan kaynaklanmaktadır [3].

Vücudun termoregülasyonu uyku sırasında, uyanık duruma göre daha az aktiftir. İnsan vücudunun termal olarak rahat hissettiği sıcaklık aralığı olan termo-nötr alanı uyuyan kişinin giysileri ve yatak bileşenleri belirler. Ortam sıcaklığındaki değişikliklerin, uykuya dalış sürelerini etkilediği, uyku yapısı değişikliklerine sebep olduğu gözlenmiştir. Yatak mikroklima sıcaklığındaki sert değişikliklerin, uyuyanları uyanmaya daha duyarlı hale getirdiği tespit edilmiştir. Uyku grubu ürünlerinden yorganların, sadece yalıtıcı ve nem emici etkileri değil, aynı zamanda vücut şekline uyum sağlama özellikleri de önemlidir. Ayrıca, elektrikli battaniyeleri de $3^{\circ} \mathrm{C}^{\prime}$ den düşük ortam sıcaklıklarında ve \%50 ile \%80'lik bağll nemde kullanmanın uyku için yararlı olduğu bulunmuştur [5]. Doğu Çin'deki genç bir grup üzerinde yapılan çalışmada, ördek tüyü, kaz tüyü ve pamuk malzemelerinden üretilen yorganların uyku kalitesi ve termal konfora olan etkileri subjektif veriler ve fizyolojik ölçümlerle incelenmiştir. Yorgan malzemesinin uyku kalitesi üzerinde önemli bir etkisi olduğu, kaz tüyü yorganın ise genel uyku konforu ve termal his açlarından daha yüksek performansa sahip olduğu tespit edilmiştir [6]. Bir başka çalışmada, yatağın sertliğinin, yatak ile temas eden vücut yüzey alanını belirleyerek mekanik ve termal konforu etkilediği tespit edilmiștir [7].

Uykuyu bölen tipik iskelet kas şikayetleri, bel ve omuz ağrılarıdır. Ortak bir inanç, sağlam bir yatağın bel ağrısı için yararlı olduğudur ancak bu iddiaları destekleyen kanıtlar eksiktir. Ortopedi cerrahlarının yaptığı bir ankette katılımcıların \%95'i sırt ağrıları üzerinde yatağın rolü olduğunu, $\% 75^{\prime}$ i ise sırt ağrısının giderilmesinde sağlam ve sert yatakların çözüm olduğunu belirtmişlerdir. Orta sert yatakların, klinik olarak tanı konmuş sırt ağrısı, omuz ağrısı olan kişilerde omurga sertliğini azalttı̆̆ ve uyku kalitesini olumlu yönde etkilediği bulunmuștur. Orta sert yatak sistemlerinin uygulanmasıyla, uyku bozuklukları olan ve uyku kalitesi düşük olan bireylerde uyku kalitesinde ve etkinliğinde önemli yararlar sağlanmıştır. Kronik bel ağrısı olan hastalarla yapılan bir çalışmada, üç farklı yatak (1. su yatağı, 2. köpük yatak, 3. sert bir yatak) değerlendirilmiş ve sonuçta köpük ve su yataklarının sert yatağa tercih edildiği tespit edilmiştir [8]. Sırt ağrısı olan hastalarda düz bir yatak ile özel olarak tasarlanmış bel gövde desteği ile donatılmış yatak karşılaştırılmış ve desteğin sırt-bel ağrısını önemli ölçüde azalttığı bulunmuştur [9].

Dünyadaki yatak üretiminin \% 40'ını yaylı, \% 45'ini sünger yataklar oluşturmaktadır. Dünyada en fazla yatak üreten ve en fazla tüketen ülkeler arasında ABD, Çin ve Brezilya ilk 3 sırada yer almaktadır. Yatak ithalatı yapan ülkeler arasında ilk 3 sırayı Almanya, Fransa ve ABD; ihracat yapan ülkeler arasında ise ilk 3 sırayı Polonya, Çin ve Belçika alırken, ihracat ve ithalat sıralamalarında Türkiye henüz ilk 10 sırada yer alamamaktadır. Türkiye yatak pazarının yüzde 95'i yaylı, yüzde 5'i sünger yataklardan oluşmaktadır. Üretici iller arasında ilk sırayı Kayseri, İstanbul ve İzmir almaktadır. Avrupa'da ortalama 2 yıl olan yatak değiștirme süresi, Türkiye'de ise 8 yllı bulmaktadır [10].

Günümüzde üretilen yataklar kullanılan hammaddeler veya uygulanan bitim işlemleriyle farklı fonksiyonelliklere sahip olabilmektedir. Kanallı veya içi boș lif kullanımıyla yüksek yalıtım ve sıvı transferi, gümüş iplik ya da doğal antibakteriyel özelliğe sahip lif kullanımıyla antibakteriyellik ve koku oluşumunu önleme gibi uygulamalar yataklarda sıkça kullanılmaktadır. Ayrıca bitim işlemleriyle leke tutmazlık, nanoteknoloji ile kendi kendini temizleme özelliği, sivrisinek ve tahtakurularına karşı koruyuculuk, antistatik ve antistress özellikler, mikrokapsül teknolojisiyle güzel koku uygulamaları, ısıtma-soğutma fonksiyonları, elektromanyetik kalkanlama fonksiyonları da kazandırılabilmektedir. Bunların yanında tamamen geri dönüșümlü malzemelerden yatak kumaşı üretimi de günümüzde sürdürülebilirlik kavramını destekler şekilde üzerinde çalışılan bir konudur [11-12].

Vücut bölgelerinin bölgesel ihtiyaçlarını karşılamak, uyku termal konforunu ve uyku kalitesini etkileyen kritik faktörlerden biridir. İnsan vücuduna temas eden bir yatak sisteminin yüzeyinin tasarımı, farklı uyku yüzeylerinin yatak sistemlerine entegre edilmesiyle gerçekleştirilmektedir. Termal uyaranlara karşı hassasiyet vücudun farklı bölümlerinde değişkenlik gösterdiği için farklı vücut segmentlerinin ihtiyaçlarına göre uyku pozisyonları ve uyku yüzeyleri arasındaki ilişki çok önemli bir tasarım konusudur. Bir yatak tasarımının kapsaması gereken 3 tasarım ilkesi; basınç dağılımı, uyku pozisyonunun kolay değişimi ve mikroklimanın fizyolojik dengesidir. Vücuttaki kemik çıkıntılarının bulunduğu yerlerde lokal nokta basınçlarından kaçınmak için rahatsızlık durumunda uyku pozisyonu değiştirilebilmeli, vücut yüzey basınçları yeniden dağıtılarak rahatsızlık azaltılmalıdır [13]. Vücut temas basıncl, vücut ağırlığının vücuda temas eden 
vücudun yüzeyine dağılımının bir ölçüsüdür. İyi tasarlanmış bir yatak sıklıkla vücuda uygulanan yüksek basınç noktalarını en aza indirme özelliğine sahip olmalıdır [3]. Bu amaçla yapılan bir çalışmada geliştirilen iki yatak üzerinde 10 katılımcı ile iki geceyi içeren, termal algıların alındığı subjektif denemeler yapılmıştır. İlk yatağın katmanları V şeklinde bağlantı ipliklerine sahip sandviç kumaş katman, X şeklinde bağlantı ipliklerine sahip isı dağılımını artırma amaçlı malzeme kullanılan katman, havalandırma ve nem iletimi katmanı ve basınç dağılımı amaçlı sandviç kumaş katmanlarından oluşmaktadır. Benzer yapıdaki ikinci yatağın katmanlarının ilk ikisi ise I şekilli sandviç kumaştan oluşmaktadır. Sonuçta, genel olarak farklı formlarda bağlantı ipliklerine sahip sandviç kumaştan üretilen ilk yatağın konfor algısının daha yüksek olduğu, bölgesel termal konfor algısında hafif bir artışın, tüm vücut termal konfor algısını artırdığı tespit edilmiştir [13]. Basınç ülserlerinden korunmak için hafiflik, iyi geçirgenlik ve üstün basınç dağllım performansları nedeniyle sandviç kumaşlar taşıt koltuklarının yanında, yataklarda da kullanılabilmektedir [14]. 3D tekstil sandviç yapının sıkıștırılma davranışını etkileyen en önemli yapı parametreleri, iplik kalınlığı, bağlantı ipliği yoğunluğu ve kumaşın eğilme davranışı olarak sıralanabilir [15].

Çift kişilik yataklarda vücut tipine göre destek sağlanması ve yatak yüzeyinde hareket transferinin minimuma indirilmesi de yataktan beklenen mekanik gereksinimler arasındadır. Yatak sistemlerinin laboratuvar destekli bir yaklaşımla değerlendirildiği bir çalışmada, yatak destek yüzeyleri ve sandviç kumaşın sağladığı aktif hava dağılımı ile viskoelastik köpükten daha etkili bir ısı transferi sağladığı tespit edilmiştir [16]. Yapılan diğer bir subjektif değerlendirme çalışmasında, plesebo etkisi ile iki özdeş yatağın 41 adet kullanıcı tarafindan kullanımı istenmiş, yataklardan biri daha pahalı ve kaliteli bir yatak olarak tanıtılmıştır. Sonuçta, daha pahalı ve kaliteli olarak tanıtılan yatağın katılımcılar tarafından beklenen ve algılanan konforunun yüksek çıktığı tespit edilmiştir [17]. Sırt ağrısının uyku kalitesine etkisi üzerine yapılan bir diğer çalışmada, 27 hastadan oluşturulmuş grubun, öncelikle kendi yataklarında yatarlarken 3 hafta boyunca yatış pozisyonları , (sırtüstü, yan, yüzüstü) ve ağrı verileri 7'li bir skalayla alınmış, daha sonra katılımcıların uyku pozisyonları ve antropometrik iskeletlerine göre belirlenen yataklarda 12 hafta boyunca ağrı şikayetleri tekrar incelenmiştir. Temel uyku pozisyonları olarak; \%58.8 oranında yan yatış, \%31.8 oranında sırt üstü yatış, \% 8.4 oranında yüzüstü yatış seçilmiştir. Çalışma sonucunda, alt sırt ağrısında \%64.6, sırt sertliğinde \%66.2, omuz ağrısında \%60.1, uyku kalitesinde \%51.0 ve uyku konforunda \%54.8 oranında iyileşmelerin olduğu görülmüştür [8]. Kumaş tutumuyla ilgili bir çalışmada, kumaş tutum test cihazı (Fabric Touch Tester - FTT) ile 12 yatak kumaşı değerlendirilmiştir. FTT ile kumaşların eğilme, sıkıştırılma, termal ve yüzey özellikleri gibi tutum parametreleri ölçülmüştür. Pürüzlülük, yumuşaklık, sıcaklık ve esneklik gibi yatak kumaşları için dokunsal özellikler uzman bir grup tarafından subjektif olarak da değerlendirilmiştir ve uzmanların verdiği ortalama puanlar ile FTT kumaş indeksleri arasındaki ilişkiler incelenmiş, seçilen değişkenler arasında kumaş gramajının tüm FTT kumaş indeksleri üzerinde en büyük etkiye sahip olduğu bulunmuştur [18]. Ortam şartları kontrol altındaki bir odada örtü altına yerleştirilen termal manken sistemi kullanılarak yatak sisteminin yalıtımının incelendiği bir çalışmada, ısı kayıpları, hava akış hızı, sıcaklık dağılımları farklı koşullar altında ölçülmüş, hava sıcaklığı ve hava akış hızının, uyuyan kişilerden çevreye olan ısı kaybını önemli ölçüde etkilediği tespit edilmiştir [7]. Uyku sırasındaki termal konfor şartlarının araştırıldığı deneysel bir çalışmada, gece boyunca ortam ve yatak mikroklima şartları ölçülmüş, termal hisler ise subjektif skalalarla değerlendirilmiştir. Sonuçlara göre, yatak mikroklima sıcaklığının ortam sıcaklığına göre çok daha dar bir aralıkta değiștiği, operasyonel sıcaklık $11.3^{\circ} \mathrm{C}$ ile $21.9^{\circ} \mathrm{C}$ arasında olduğunda yüz bölgesi için termal konfor koşuluna ulaşılabildiği sonucuna varılmıştır. Yatak sisteminin $30.3^{\circ} \mathrm{C}$ ile $32.5^{\circ} \mathrm{C}$ arasında olması gerektiği, bu şartlarda yatağın 3.73 clo'luk termal dirence sahip olduğu tespit edilmiştir [19].

Yatak konfor ve kalitesinin sağlı ve performans üzerindeki etkilerinin incelendiği ve yatak özelliklerinin vücut ihtiyaçlarına göre geliştirildiği çalışmalar ışığında, bu çalışmada insanların satın aldıkları yataktan beklentileri ile sağlık ve konfor problemleri bir grup tüketiciye uygulanan anket ile incelenmiştir. Çalışma sonuçlarının, kaliteli uyku gereksinimleri, yatak kumaşına kazandırılan fonksiyonel özelliklerin ve yatak mikroklimasında sağlanan termal konforun tüketiciler için önemi konularında üretici ve araștırmacılara katkı sağlayabileceği düşünülmektedir.

\section{Materyal ve Metot}

\subsection{Katılımcı özellikleri}

Süleyman Demirel Üniversitesi Tekstil Mühendisliği Bölümünde yürütülmekte olan bir yüksek lisans tezi kapsamında yapılan bu anket çalışmasının amacı, kişilerin yatak tercihinde önem verdikleri parametrelerin ve yatakla ilgili yaşadıkları problemlerin belirlenmesidir. Farklı özelliklere ve mesleklere sahip 320 kişilik bir grup üzerinde gerçekleştirilen anket çalışmasının katılımcılarının kişisel özellikleri Tablo 1'de verilmiștir. Tabloda da görüldüğü gibi katılımcı grubu büyük oranda lisans eğitimine sahip genç ve orta yaşlı tüketicilerden oluşmaktadır. Yatak konfor ve gereksinimleri konusunda bilinç sahibi ve belirli bir gelir düzeyinin üzerindeki katılımcılarda kadın-erkek dengesinin de sağlanmasına özen gösterilmiștir. 
Tablo 1. Katılımcların kisisel bilgileri

\begin{tabular}{|l|l|l|l|l|l|}
\hline $\begin{array}{l}\text { Yaş } \\
\text { Aralığı }\end{array}$ & $\%$ & Cinsiyet & $\%$ & $\begin{array}{l}\text { Öğrenim } \\
\text { Durumu }\end{array}$ & $\%$ \\
\hline $18-30$ & 53 & Kadın & 52 & İlköğretim & 2 \\
\hline $31-45$ & 28 & Erkek & 48 & Lise & 15 \\
\hline $46-60$ & 17 & & & Önlisans & 18 \\
\hline $\begin{array}{l}60 \text { ve } \\
\text { üzeri }\end{array}$ & 2 & & & Lisans & 53 \\
\hline & & & & $\begin{array}{l}\text { Yüksek } \\
\text { lisans }\end{array}$ & 12 \\
\hline
\end{tabular}

\subsection{Anket soruları}

Anketteki ilk sorular katılımcılara ait kişisel bilgilerle ilgili olup, katılımcıların satın alma davranıșları, kaliteli bir uyku için önemli parametreler, yatakta hissedilen ağrı bölgeleri, reklamların satın alma davranışları üzerindeki etkileri, satın alınan üründen memnuniyet dereceleri ve kullanılan yatak değişim süresi gibi sorulara cevap aranmıştır. Değerlendirme için 5-noktalı subjektif değerlendirme skalası kullanılmış ve değerlendirmeler ' 1 ' 'hiç önemli değil' ile '5' "olmazsa olmaz" arasında değişmektedir.

- İlk 6 soru katılımcıların kişisel bilgilerini elde etmeye yöneliktir.

- Yedinci soru, kaliteli bir uyku için önemli parametreleri belirlemeye yöneliktir.

- Sekizinci soru, varsa ağrı bölgelerinin belirlenmesine yöneliktir.

- Dokuzuncu soru, ev akarlarına karşı yaşanan sorunlara yöneliktir.

- Onuncu ve onbirinci sorularda, uyku sirasinda yaşanan terlemenin uyku kalitesini etkileme durumu değerlendirilmiştir.

- Onikinci soruda, yatak seçiminde etkili özellikleri değerlendirmek için 5-noktalı subjektif değerlendirme skalası kullanılmıștır.

- On üçüncü ve on dördüncü sorularda, bebek yatakları tercih edilirken onikinci soruda verilen parametrelerden farklı bir özellik varsa eklemeler yapılması istenmiştir.

- On beșinci, on altıncı ve on yedinci sorular, yatakla ilgili reklamlarda bahsedilen fonksiyonel özelliklerin satın alma davranışı üzerindeki etkileri ve satın alınan üründen memnuniyet derecesi ile ilgilidir.

- Onsekizinci soru, katılımcların yatak değişim süreleri hakkındadır.

Katılımcılar, anketin farklı bölümlerinde yer alan açık uçlu sorulara kişisel görüşlerini ekleyebilmişlerdir.

\section{3 İstatistiksel yöntem}

Ankette verilerin yorumlanmasında kullanılan faktör analizi yöntemi, nitelikler arasındaki ilişkileri belirleyerek farklı gruplar halinde özetleme için kullanışlı bir araçtır. Anket sonunda katılımcıların yatak tercihinde etkili olan özellikler faktör analizi metodu ile aralarındaki ilişkilere göre faktör alt gruplarına ayrılmıştır. $\mathrm{Bu}$ metot ile elde edilen bileşen matrisine uygulanan döndürme (rotation) işlemi, faktörlerin pozisyonlarına göre, yani faktör ağırlıklarının yüksek (1 veya -1'e yakın) veya düşük (0'a yakın) olmasına göre grupların tekrar düzenlenmesini sağlamaktadır. Böylece bileșenlerin faktör alt gruplarına ayrılması daha anlaşılır bir hale gelmektedir [20].

\section{Bulgular}

Tüketici davranışlarının incelenmesi, özellikle pazar fırsatlarının değerlendirilmesi açısından önemli avantajlar sağlamaktadır. Tüketici istek ve ihtiyaçlarının doğru bir şekilde ortaya konması, hedef kitlenin belirlenmesi ve bu hedef kitleye yönelik olarak gerçekleştirilecek pazarlama faaliyetlerinin başarısında büyük rol oynamaktadır [21].

Kaliteli uyku için önem verilen parametrelerin incelendiği bölümde, önemli parametrelerin katılımcıların yaşlarına göre değişimleri Şekil 1'de görülmektedir. Şekil 1'deki yaş grupları incelendiğince, tüm yaşlar için en önemli parametrenin 'yatak konforu' olduğu, bunu 'ortam sessizliği' ve 'ortam sıcaklığı' parametrelerinin takip ettiği ve 'ortam aydınlatması'nın en az önem verilen faktör olduğu tespit edilmiştir. Genel olarak yatak konforunun yaş geçtikçe daha önemli hale geldiği de elde edilen bulgular arasındadır. Yatak seçiminde önem verilen parametreler katılımcıların boylarına ve ağırlıklarına göre incelendiğinde ise net bir eğilim elde edilememiștir.

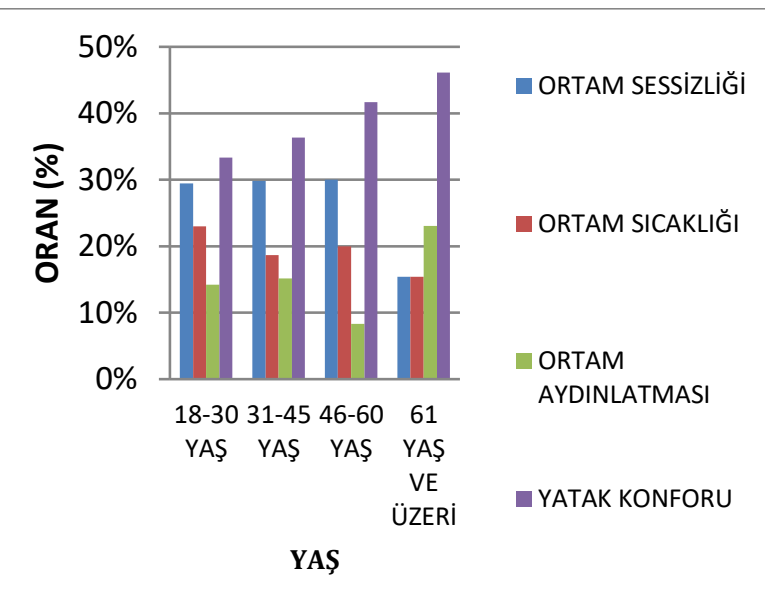

Şekil 1. Kaliteli uyku için önem verilen parametrelerin yașa göre değişimi

Katılımcıların vücutlarında özellikle yatarken hissettikleri kronik ağrlların yaşa göre değişimi Şekil 2 'de verilmiştir. Ankete en çok katılımın sağlandığ 18-30 yaş grubu sırasıyla, \% 24 oranla sırt/omurga, $\% 22$ oranla bel, \% 18 oranla boyun, \% 14 oranla omuz, \% 15 oranla ağrı hissetmeyenler, \% 6 oranla 
bacak ağrısı olan katılımcılardan oluşmuştur. Genel olarak tüm yaş grupları için sırt/omurga ve bel ağrılarının belirgin olduğu, sırt omurga ağrılarının yaşla birlikte arttığı tespit edilmiştir. Basen ağrısının 320 kişiden sadece 4 kişide bulunduğu, boyun ağrısının yaş ile azalış, bacak ağrısının ise artış gösterdiği tespit edilmiştir.

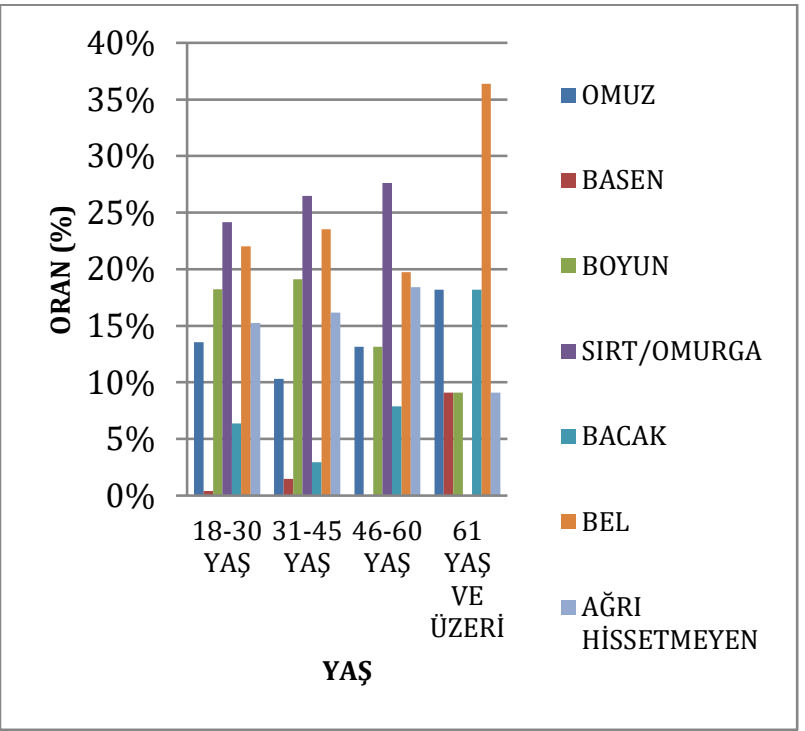

Şekil 2. Hissedilen ağrı bölgelerinin yaşa göre değişimi

Ev akarları, her türlü kumaş türünde yaşayabilen, özellikle nemli ve sıcak ortamlarda hızla çoğalan, insanların deri döküntüleri ile beslenen, insanlarda alerjiye neden olan mikroskobik canlılardır. Özellikle, yatak, yastık, yorgan, halı, kalın kumaşlı perde ve mobilya gibi üzerinde çok kolay toz tutabilen ev eşyalarında yüksek oranda bulunur [22]. Ev akarlarına karşı alerji durumu ile ilgili soruda, katılımcıların \% 15'i alerjilerinin olduğunu belirtmişlerdir.

Vücuttan uzaklaştırılamaması durumunda vücut termal konforunu büyük oranda düşüren terleme, giysi sisteminde olduğu gibi yatak mikroklimasını oluşturan tekstil yapıları açısından da oldukça önemlidir. Anket sonuçlarına göre, uyku sırasında herhangi bir sebepten dolayı terleme yaşayan katılımcıların oranı \%51 olarak tespit edilmiştir. Şekil 3'te uyku sırasında terleme yaşayan katılımcıların bu durumdan rahatsızlık dereceleri görülmektedir. Görüldüğü gibi, kişilerin yaklaşık \%56'sı terli durumdan az miktarda rahatsız olduklarını, \% 30'u ise terden 'ciddi derecede' ile 'tahammül edilemeyecek kadar' arasında değișen oranlarda yüksek rahatsızlık duyduklarını belirtmişlerdir.

Subjektif olarak değerlendirilen yatak seçiminde etkili 20 özelliğin ortalama puanları ve standart sapmaları Tablo 2'de verilmiştir. Elde edilen sonuçlara bakıldığında, yatak tercihinde en etkili özelliğin 3.90 puanla ortopedik/mekanik destekleme, en az önem verilen özelliğin ise 2.82 puanla yay

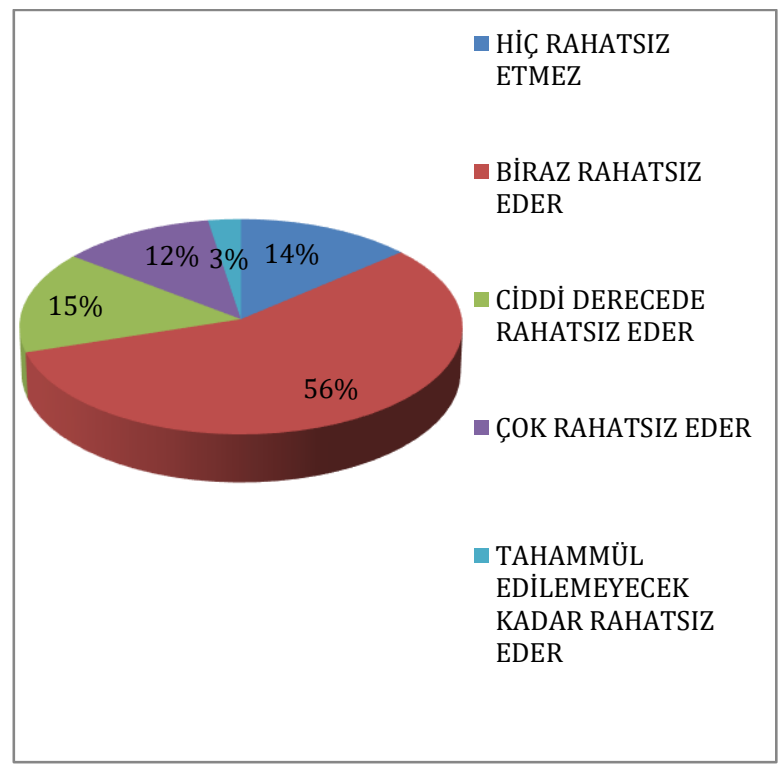

Şekil 3. Uyku sırasında yaşanan terlemenin yaşattığı rahatsızlık dereceleri

özellikleri olduğu tespit edilmiștir. Katılımcıların yatakta en önem verdikleri diğer özellikler tasarım, kir itici ve kolay temizlenebilir olması, kumașın yeterli geçirgenlik özellikleriyle terletmemesi, standartlara uygunluk sertifikasının olması, kumaşın ve dolgu malzemesinin hammaddeleri olarak tespit edilmiştir. Giysi tercihlerinde olduğu gibi [23] yatak seçiminde de estetik özellikler önemini korumakta, kullanım kolaylığıyla ilgili fonksiyonellik, hammadde ve buna bağlı olarak termal konfor performansı da kullanıcıların dikkat ettiği en önemli parametreler arasında yer almaktadır. Tablo 2'de görülen ortak yük değeri, her bir faktörün 0 ile 1 arasında değișen ortak varyansını göstermektedir. Yüksek ortak yük değeri, o faktörün varyansın daha fazlasını açıklayabildiğini göstermektedir [20]. Tablo 2'de görülen ortak yük değerlerinin en az 0.30 olması gerekmektedir. Aksi takdirde faktör analizinden çıkarılıp tekrar işlem yapılması gerekmektedir. Tablo 2'de görüldüğü gibi özelliklerin tümünün yük değerleri 0.30 değerinin üzerinde çıkmış, değerlendirmeden çıkarılan bir parametre olmamıştır. Ortak yük değerlerine bakıldığında, yatak kumaşında kullanılan hammadde \% 78.9'luk varyans açıklama yüzdesiyle, aldığı ortalama skorla da orantılı olarak yatak seçimini etkileyen en önemli parametre olmuştur. Yine hammadde grubunda yer alan yatak dolgu malzemesi ve yay özelliği ise sırasıyla \% 75.9 ve \% 71.5 varyans açıklama yüzdeleriyle önemli parametreler arasında yer almıştır. $\mathrm{Bu}$ özellikler dışında yatak yüksekliği, üst yüzey kumaşının antialerjik, antibakteriyel özellikte olması ile yatağın tasarımı, fiyatı ve markası da yatak tercihlerinde ön planda olan parametrelerdir. Buradan, yatak tercihinde tekstil bileșenlerinin yanı sıra yay, viskoelastik dolgu malzemesi gibi diğer malzemeler ile tüm ürünlerde olduğu gibi tasarım, marka ve fiyatın etkili olduğu sonucuna varılabilir. 
Tablo 2. Yatak özellikleri

\begin{tabular}{|c|c|c|c|}
\hline Özellikler & Ortalama & $\begin{array}{c}\text { Standart } \\
\text { Sapma }\end{array}$ & $\begin{array}{c}\text { Ortak } \\
\text { Yük } \\
\text { Değeri }\end{array}$ \\
\hline Dayanıklılık, sağlamlık & 3.57 & 0.88 & .520 \\
\hline $\begin{array}{c}\text { Ortopedik/mekanik } \\
\text { destekleme özellikleri }\end{array}$ & 3.90 & 0.94 & .580 \\
\hline $\begin{array}{c}\text { Antibakteriyel özellikli } \\
\text { olma }\end{array}$ & 3.54 & 0.95 & .645 \\
\hline $\begin{array}{l}\text { Hava/su buharı } \\
\text { geçirgenliği ile } \\
\text { terletmeyen bir kumaş }\end{array}$ & 3.71 & 0.94 & .578 \\
\hline $\begin{array}{l}\text { Antialerjik özellikli } \\
\text { olma }\end{array}$ & 3.47 & 1.01 & .677 \\
\hline $\begin{array}{l}\text { Antistatik özellikli } \\
\text { olma }\end{array}$ & 3.24 & 1.00 & .629 \\
\hline $\begin{array}{c}\text { Kir itici ve kolay } \\
\text { temizlenebilir özellikli } \\
\text { olma }\end{array}$ & 3.75 & 0.94 & .587 \\
\hline $\begin{array}{c}\text { Kumaş yüzeyinde } \\
\text { boncuklanma } \\
\text { oluşmaması }\end{array}$ & 3.45 & 1.00 & .584 \\
\hline $\begin{array}{c}\text { Standartlara uygunluk } \\
\text { sertifikasının olması }\end{array}$ & 3.64 & 1.02 & .538 \\
\hline $\begin{array}{c}\text { Çevre dostu ve geri } \\
\text { dönüsstürülebilir } \\
\text { olması }\end{array}$ & 3.40 & 1.06 & .575 \\
\hline $\begin{array}{c}\text { Sıcaklık/serinlik hissi } \\
\text { oluşturması }\end{array}$ & 3.41 & 0.96 & .584 \\
\hline $\begin{array}{c}\text { Bitkisel özlerin yatak } \\
\text { kumaşına uygulanması }\end{array}$ & 3.10 & 1.10 & .610 \\
\hline $\begin{array}{c}\text { Güç tutuşur özellikte } \\
\text { olması }\end{array}$ & 3.31 & 1.10 & .582 \\
\hline $\begin{array}{c}\text { Dolgu maddesinin } \\
\text { doğal ya da sentetik } \\
\text { olması }\end{array}$ & 3.61 & 1.00 & .759 \\
\hline $\begin{array}{c}\text { Yatak kumaşında } \\
\text { kullanılan hammadde }\end{array}$ & 3.71 & 1.02 & .789 \\
\hline Yatak yüksekliği & 3.19 & 1.04 & .660 \\
\hline Yay özelliği & 2.82 & 1.09 & .715 \\
\hline Tasarım & 3.75 & 0.96 & .676 \\
\hline Fiyat & 3.62 & 0.98 & .610 \\
\hline Marka & 3.01 & 1.16 & .618 \\
\hline
\end{tabular}

Belirlenen 20 yatak özelliği için elde edilen subjektif skala değerlerine faktör analizi uygulandığında, özellikleri benzer skor değerlerine göre aynı gruplara koyan döndürülmüş bileşen matrisi Tablo 3'te görülmektedir. Analiz sırasında farklı faktör grup sayıları da denenmiş, fakat özelliklerin dört grup altında toplanmasının toplam \% 62.59 varyans açıklama yüzdesiyle uygun olduğu sonucuna varılmıştır. Tablo 3'te görüldüğü gibi, antialerjik, antibakteriyel, antistatik, kir itici/kolay temizlenebilme özellikleri ile sıcaklı/serinlik hissi oluşturma, bitkisel özlerin yatak kumaşına uygulanması ile kazandırılan fonksiyonellikler gibi hammadde veya bitim işlemleri ile ilgili özellikler, kumaş yüzeyinde oluşan boncuklanma, hava/su buharı geçirgenliği, çevre dostu ve geri dönüștürülebilir malzeme kullanılması gibi yapısal özellikler ve standartlara uygunluk sertifikasının bulunması \% 25.30' luk varyans açılklama yüzdesi ile aynı grupta yer almışlardır. Yatak kumaşında ve dolgu malzemesi olarak kullanılan hammadde ve güç tutuşurluk özelliği ise \% 13.71'lik varyans açıklama yüzdesiyle ikinci faktör grubunu oluşturmuştur. Yay özelliği, marka ve yatak yüksekliği gibi tekstil dışı bileşenlerle ilgili özellikler \% 11.88'lik varyans açılama yüzdesiyle üçüncü faktör grubunu olușturmuștur. Dördüncü ve en az öneme sahip olarak seçilen faktör grubu özellikleri ise (\% 11.70 varyans açıklama yüzdesiyle), fiyat, tasarım, dayanıklılık/sağlamlık, ortopedik/mekanik destekleme özelliklerini içermiştir. Sonuçlara göre, yatağın tekstil bileşenlerinin hammaddeleri ile uygulanan bitim işlemleri ve kumaş yapısıyla sağlanan sağlık, konfor, kullanım ve çevresel etki performansını iyileştirme uygulamalarının yatak tercihinde ön planda olduğu tespit edilmiştir. Marka, fiyat, tasarım ve bileșenleri ile sağlamlık ve ortopedik/mekanik desteklerin ise kriterler arasında daha az öncelikli olduğu tespit edilmiștir. Literatürde, özellikle medikal yataklarda basınç dağılımının iyileștirilerek basınç yaralarını azaltma konusundaki çok sayıda çalışma ve katılımcıların büyük çoğunluğunun yaşadığı bel ve omurga/sırt sorunları düşünüldüğünde, ortopedik/mekanik destekleme özelliğinin öncelikli parametreler arasında yer almaması beklenmeyen bir sonuçtur.

Anketin bir diğer bölümünde, çocuğu olan katılımcıların dikkat ettikleri diğer parametreler sorulmuştur. Çoğunluk, sıralanan özellikleri yeterli bulmuș, ek olarak yine bir önceki bölümde de önem verilen hammadde başlığıyla ilgili, organik hammaddelerin kullanımı konusu belirtilmiştir.

Katılımcların tüm ürünler için satın alma davranışlarını etkileyen reklamların yatak seçimi üzerindeki etkileriyle ilgili soruya, katılımclların \% 67'si yatakla ilgili reklamlarda iddia edilen fonksiyonel özelliklerin satın alma davranıșlarını etkilediğini belirtmişlerdir. Katılımcıların cinsiyetlerine göre gruplandırma yapıldığında ise, kadınların reklamlardan etkilenme oranını \% 76 iken, erkeklerin oranı \% 59 olmuştur.

Reklamlardan etkilendiğini belirten gruba reklamda belirtilen hangi özelliğin etkili olduğu sorulduğunda, en çok \% 34 oranla ortopedik özelliklerin etkili 
Tablo 3. Yatak seçiminde özelliklerin dönüștürülmüş bileșen matrisi

\begin{tabular}{|c|c|c|c|c|}
\hline Özellikler & Grup1 & Grup2 & Grup3 & Grup4 \\
\hline $\begin{array}{l}\text { Antialerjik özellikli } \\
\text { olma }\end{array}$ & 0.749 & - & - & - \\
\hline $\begin{array}{l}\text { Antibakteriyel özellikli } \\
\text { olma }\end{array}$ & 0.748 & - & - & - \\
\hline $\begin{array}{l}\begin{array}{l}\text { Antistatik } \\
\text { olma }\end{array} \\
\text { özellikli }\end{array}$ & 0.709 & - & - & - \\
\hline $\begin{array}{l}\text { Kumaş yüzeyinde } \\
\text { boncuklanma } \\
\text { oluşmaması }\end{array}$ & 0.694 & - & - & - \\
\hline $\begin{array}{l}\text { Kir itici ve kolay } \\
\text { temizlenebilir özellikli } \\
\text { olma }\end{array}$ & 0.682 & $\begin{array}{lll}- & -\end{array}$ & $\begin{array}{lll}- & -\end{array}$ & - \\
\hline $\begin{array}{l}\text { Çevre dostu ve geri } \\
\text { dönüştürülebilir } \\
\text { olması }\end{array}$ & 0.662 & $\begin{array}{lll}- & -\end{array}$ & - & - \\
\hline $\begin{array}{l}\text { Sicaklık/serinlik hissi } \\
\text { oluşturması }\end{array}$ & 0.589 & - & - & - \\
\hline $\begin{array}{lr}\text { Hava/su } & \text { buharı } \\
\text { geçirgenliği } & \text { ile } \\
\text { terletmeyen bir kumaş }\end{array}$ & 0.576 & $\begin{array}{ll}- & - \\
\end{array}$ & - & - \\
\hline $\begin{array}{l}\text { Bitkisel özlerin yatak } \\
\text { kumaşına } \\
\text { uygulanması }\end{array}$ & 0.565 & - & - & - \\
\hline $\begin{array}{l}\text { Standartlara uygunluk } \\
\text { sertifikasının olması }\end{array}$ & 0.518 & - & - & - \\
\hline $\begin{array}{l}\text { Yatak kumaşında } \\
\text { kullanılan hammadde }\end{array}$ & - & 0.826 & - & - \\
\hline $\begin{array}{ll}\text { Dolgu } & \text { maddesinin } \\
\text { doğal ya da } & \text { sentetik } \\
\text { olması } & \end{array}$ & - & 0.786 & - & - \\
\hline $\begin{array}{l}\text { Güç tutuşur özellikte } \\
\text { olması }\end{array}$ & - & 0.474 & - & - \\
\hline Yay özelliği & - & - & 0.786 & - \\
\hline Marka & - & - & 0.694 & - \\
\hline Yatak yüksekliği & - & - & 0.686 & - \\
\hline Fiyat & - & - & - & 0.701 \\
\hline Tasarım & - & - & - & 0.620 \\
\hline Dayanıklılık, sağlamlık & - & - & - & 0.598 \\
\hline $\begin{array}{l}\text { Ortopedik/mekanik } \\
\text { destekleme özellikleri }\end{array}$ & $\begin{array}{lll}- & -\end{array}$ & $\begin{array}{lll}- & -\end{array}$ & - & 0.536 \\
\hline $\begin{array}{l}\text { Açıklanan varsans } \\
(\%)\end{array}$ & 25.30 & 13.71 & 11.88 & 11.70 \\
\hline
\end{tabular}

olduğu, bunu kolay temizlenebilme/kir iticilik antibakteriyellik, antistress özelliği ve çevresel etkilerinin takip ettiği tespit edilmiştir (Şekil 4). Yataklarla ilgili yapılan çok sayıda fonksiyonelliği içeren reklamların etkili olduğu, bunlar içerisinde ise yatağın ortopedik olarak omurgayı desteklemesinin diğer sağlık, kullanım kolaylığı ve çevresel özelliklerle birlikte ön planda olduğu tespit edilmiştir.

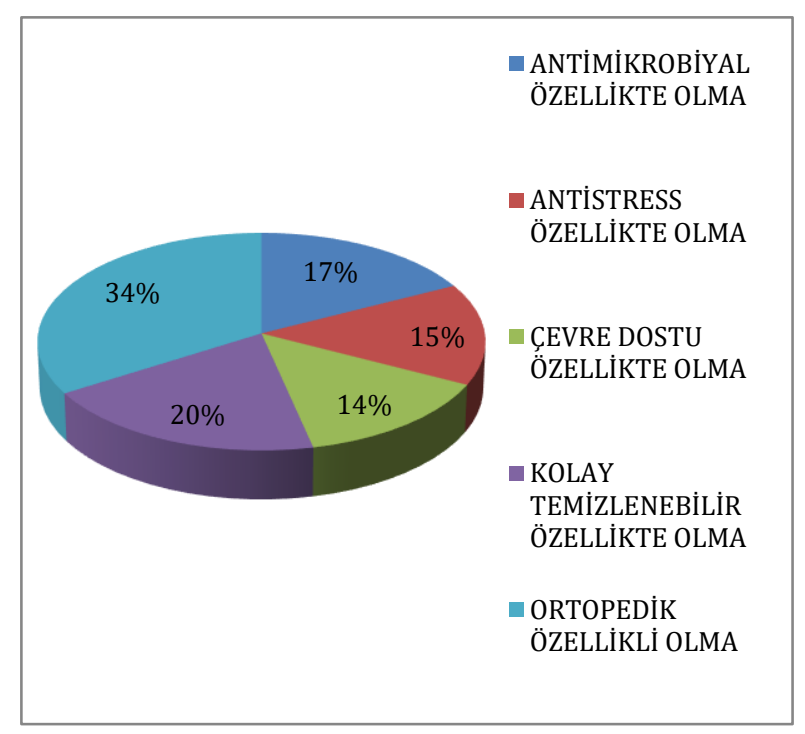

Şekil 4. Yatak reklamlarından etkilenerek tercih edilen özellikler

Ayrıca kişilere, reklamlardan etkilenerek satın aldıkları ürünün günlük yaşamdaki memnuniyet dereceleri sorulduğunda ise, \%13 oranda çok memnun oldukları, \% 77 oranında memnun oldukları, \% 10 oranında memnun olmadıkları tespit edilmiştir (Şekil 5). Genel olarak yataklar için reklamlarda belirtilen özelliklerin tüketicileri memnun edecek derecede ürünlerde mevcut olduğu sonucuna varlabilir.

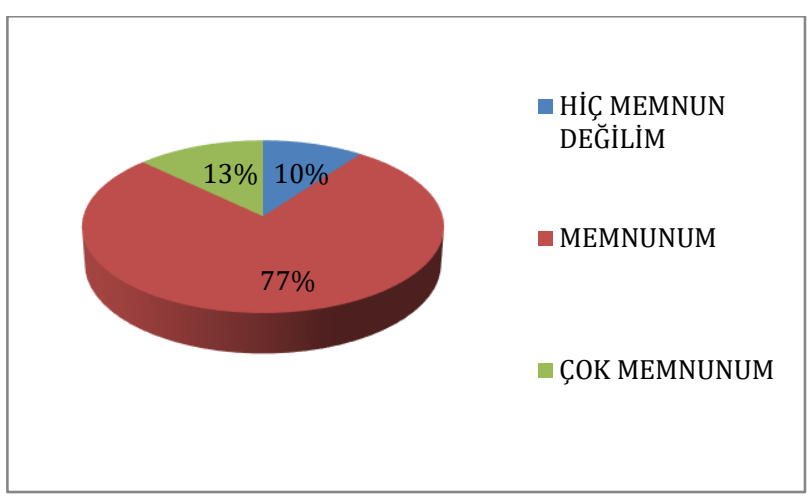

Şekil 5. Reklamlardan etkilenerek tercih edilen yatakların kullanım sırasındaki memnuniyet dereceleri

Katılımcıların yatak değişim sürelerinin sorulduğu soruya, \% 36'lık en yüksek oranla 6-9 yıl aralığında yatakların değiştirildiği belirtilmiştir (Şekil 6). Bu durum daha önce markalarla ilgili yapılan bir araştırma sonucuyla da uyumludur [10]. \% 39 oranındaki bir katılımcı grubunun ise yatağını 9 yıl ve daha fazla sürelerde kullandığı sonucuna dayanılarak 
kişilerin satın aldıkları yatakları uzun yıllar kullanma eğiliminde oldukları belirtilebilir.

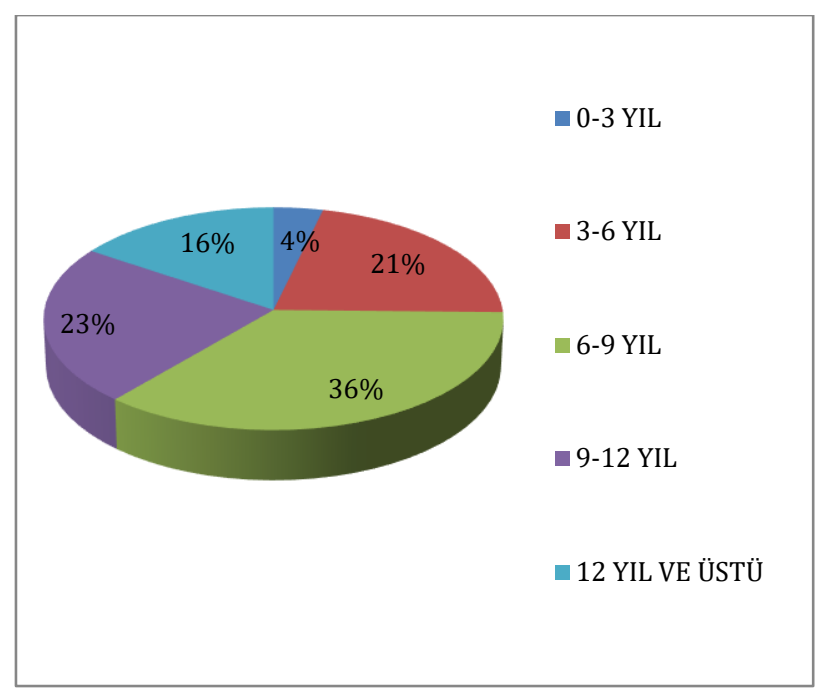

Şekil 6. Kişilerin tercih ettikleri yatak değişim süreleri

\section{Tartışma ve Sonuç}

Bir yüksek lisans tezinin ilk aşaması olarak gerçekleştirilen anket çalışması; uyku konforuna etki eden faktörleri, tüketicilerin yatak tercihinde önem verdikleri parametreleri, satın alma davranışına reklamların etkisini ve tercih edilen yataklarda yaşanan problemleri belirlemek amacıyla yapılmıștır. Elde edilen sonuçlara göre, yatak üst katman hammaddeleri (kumaş ve dolgu), uygulanan fonksiyonel bitim işlemleri, termal konfor ve çevresel özellikler yatak seçiminde ön plana çıkmıştır. Uyku kalitesini etkileyen en önemli parametre yatak konforu olarak tespit edilirken katılımcıların en fazla sirt/omurga ve bel bölgelerindeki ağrlardan şikayetçi oldukları tespit edilmiştir. Literatürde daha çok vücut basınç dağılımı ile ilgili yapılmış anketler mevcut iken termal konfor bileșenlerinin de yatak konforunda etkili olduğu, buna bağlı olarak katılımcıların büyük miktarının yatakta oluşan terden olumsuz yönde etkilendikleri tespit edilmiştir. Anket çalışmasıyla ilgili bir diğer bulgu ise, katılımclların ortopedik özellikler ile antimikrobiyellik ve kolay temizlenme özellikleri konusunda reklamlardan etkilenmeleridir. Yatak değiștirme süreleri ise büyük bir katılımcı grubu tarafindan 6-9 yll ve daha fazla olarak belirtilmiştir. Bu sonuçlar sadece ankette yer alan katılımcı grubu için geçerlidir.

\section{Kaynakça}

[1] Terliksiz, S. 2012. Sandviç kumaşların termal konfor özellikleri. İstanbul Teknik Üniversitesi, Fen Bilimleri Enstitüsü, Yüksek Lisans Tezi, 141s, İstanbul.

[2] Lafçı, D. 2009. Müziğin kanser hastalarının uyku kalitesi üzerine etkisi. Çukurova Üniversitesi, Sağlık Bilimleri Enstitüsü, Yüksek Lisans Tezi, 37s, Adana.
[3] Low, F. Z., Chua, M. C. H., Lim, P. Y., Yeow, C. H. 2017. Effects of Mattress Material on Body Pressure Profiles in Different Sleeping Postures. Journal of Chiropractic Medicine, 16(1), 1-9.

[4] Balcl, K. 2017. Başkent Üniversitesi Ankara Hastanesi'nde çalışan yetişkin bireylerin beslenme durumları ile uyku kalitesi arasındaki ilişkinin değerlendirilmesi. Başkent Üniversitesi Sağlık Bilimleri Enstitüsü, Yüksek Lisans Tezi, 10s, Ankara.

[5] Amrit, U. R. 2007. Bedding Textiles and Their Influence on Thermal Comfort and Sleep. AUTEX Research Journal, 8(4), 252-254.

[6] He, M., Lian, Z., Chen, P. 2017. Effect of Quilt Materials on Sleep Quality and Thermal Comfort for Young People in East China. Procedia Engineering, 205, 43-49.

[7] Pan, D. M., Liang, X. I. A., Chan, M. Y. 2012. Experimental Study of Thermal Environment in a Room with Mixing Ventilation. World Academy of Science, Engineering and Technology, International Journal of Civil, Environmental, Structural, Construction and Architectural Engineering, 6(5), 337-341.

[8] Jacobson, B. H., Boolani, A., Dunklee, G., Shepardson, A., Acharya, H. 2010. Effect of Prescribed Sleep Surfaces on Back Pain and Sleep Quality in Patients Diagnosed with Low Back and Shoulder Pain. Applied Ergonomics, 42(1), 91-97.

[9] Derman, K. L., Derman, E. W., Noakes, T. D. 1995. A Lumbar Body Support (KBS 2000) Alters Lumbar Muscle Recruitment Patterns in Patients with Acute-upon-Chronic Lower Back Pain. South African Medical Journal, 85(4).

[10] Durak M. 2013. http://brandtalks.org/2013/09/yataksektorunu-masaya-yatiralim-mi/ (Erişim tarihi: 11.02.2018)

[11] www.istikbal.com.tr (Erişim tarihi: 20.02.2018)

[12] www.boyteks.com.tr (Erişim tarihi: 20.02.2018)

[13] Tan, S. H., Shen, T. Y., Wu, F. G. 2015. Design of an Innovative Mattress to Improve Sleep Thermal Comfort Based on Sleep Positions. Procedia Manufacturing, 3, 5838-5844.

[14] Du, Z., Wu, Y., Li, M., He, L. 2015. Analysis of Structure of Warp-Knitted Spacer Fabric on Pressure Indices. Fibers and Polymers, 16(11), 2491-2496.

[15] Xu-Hong, M., Ming-Qiao, G. 2008. The Compression Behaviour of Warp Knitted Spacer Fabric. Fibres and Textiles in Eastern Europe, 16(1), 90.

[16] Worsley, P. R., Bader, D. L. 2018. A Modified Evaluation of Spacer Fabric and Airflow 
Technologies for Controlling the Microclimate at the Loaded Support Interface. Textile Research Journal, 0040517518786279.

[17] Naddeo, A., Cappetti, N., Califano, R., Vallone, M. 2015. The Role of Expectation in Comfort Perception: the Mattresses' Evaluation Experience. Procedia Manufacturing, 3, 47844791.

[18] Vasile, S., Malengier, B., De Raeve, A., Deruyck, F. 2017. Influence of Selected Production Parameters on the Hand of Mattress Knitted Fabrics Assessed by the Fabric Touch Tester. Textile Research Journal, 0040517517736471.

[19] Song, C., Liu, Y., Zhou, X., Liu, J. 2015. Investigation of Human Thermal Comfort in Sleeping Environments Based on the Effects of Bed Climate. Procedia Engineering, 121, 11261132.
[20] Karaman, C., Kaplan, S. 2017. Çorap Konfor ve Performans Özellikleriyle İlgili Tüketici Beklentileri. Pamukkale University Journal of Engineering Sciences, 23(7).

[21] Çakır, M., Çakır, F., Gülșah, U. S. T. A. 2010. Üniversite Öğrencilerinin Tüketim Tercihlerini Etkileyen Faktörlerin Belirlenmesi. Organizasyon ve Yönetim Bilimleri Dergisi, 2(2).

[22] http://www.aid.org.tr/hastaliklar/alerjenlerden -korunma-onlemleri/akarlar/ (Erişim tarihi: 25.12.2018).

[23] Kaplan, S., Okur, A. 2008. The Meaning and Importance of Clothing Comfort: A Case Study for Turkey. Journal of Sensory Studies, 23(5), 688-706. 